\title{
Plasma levels of resistin predict cardiovascular events
}

\section{Nivelele plasmatice ale resistinei prezic evenimente cardiovasculare}

\author{
Luminiţa Vida-Simiti, Irina Todor, Mirela Stoia, Claudia Gherman, \\ Cerasela Goidescu \\ “Iuliu Hațieganu” University of Medicine and Pharmacy from Cluj-Napoca, County Emergency \\ Clinical Hospital from Cluj Napoca, Romania
}

\begin{abstract}
Background: A number of cytokines and adipokines secreted by adipose tissue may influence vessel wall directly. Adiponectin exhibits anti-inflammatory and atheroprotective actions. Resistin is expressed at higher levels in inflammatory cells. Resistin directly activates the endothelium through upreglation of adhesion molecules, induces production of TNF- $\alpha$ by macrophages, effects that are antagonized by adiponectin. Leptin has multiple effects on cells of artery walls, many similar to those of resistin. The prognostic role of adipokines in atherosclerosis is not well established. Methods: We compared the baseline plasma levels of adiponectin, resistin, leptin and TNF- $\alpha$ (ELISA assays) in 59 patients with coronary artery disease (CAD) and 32 patients with peripheral artery disease (PAD). Also, we investigated the impact of baseline plasma levels of adiponectin, resistin, leptin and TNF- $\alpha$ on the incidence of the new ischemic cardiovascular events. Results: In patients with CAD, as compared with PAD, baseline plasma levels of leptin were significantly increased $(2882.02 \pm 368.57 \mathrm{pg} / \mathrm{ml} \mathrm{vs} 1025.56 \pm 232.28 \mathrm{pg} / \mathrm{ml}$; $p<0.001)$, plasma levels of resistin were significantly decreased $(13.15 \pm 0.83 \mathrm{ng} / \mathrm{ml} \mathrm{vs} 17.76 \pm 2.13 \mathrm{ng} / \mathrm{ml} ; \mathrm{p}=$ $0.02)$ and no differences in plasma levels of adiponectin and TNF- $\alpha$ were found. A significant correlation between BMI and plasma levels was found only for leptin, irrespective of group. 45 patients (49.5\%) were re-hospitalized in a 2 years period of follow-up. In a backward stepwise multivariable Cox regression analysis only resistin $\geq 15 \mathrm{ng} /$ $m l, H R=1.8829,95 \%$ CI 1.0490- 3.3797, $p=0.034$ and diastolic blood pressure $\geq 85 \mathrm{mmHg}, \mathrm{HR}=2.0927,95 \% \mathrm{CI}$ 1.0782- 4.0616, $p=0.0299$ were associated with new cardiovascular events. Conclussion: In patients with clinical atherosclerosis plasma levels of resistin predict new ischemc events.
\end{abstract}

Keywords: resistin, leptin, coronary artery disease, peripheral arterial occlusive disease

\section{Rezumat}

Introducere: Un număr de citokine ş̧i adipokine secretate de ţesutul adipos pot influenţa direct peretele vascular. Adiponectina exercită efecte anti-inflamatorii şi ateroprotective. Resistina este exprimată în cantităţi crescute în celulele inflamatorii. Resistina activează direct endoteliul prin suprareglarea moleculelor de adeziune, induce producţia de TNF- $\alpha$ in macrofage, efecte antagonizate de adiponectină. Leptina are multe efecte asupra celulelor din peretele arterial, unele similare cu efectele resistinei. Rolul prognostic al adipokinelor în ateroscleroză nu este bine precizat. Metode: Nivelele bazale ale adiponectinei, resistinei, leptinei şi TNF- $\alpha$ (ELISA) la pacienţi cu

*Corresponding author: Luminița Vida-Simiti, No 3-5 Clinicilor Street, 400006 Cluj-Napoca, Romania, fax:0264 590899, e-mail: lvscardio@yahoo.com 
cardiopatie ischemică au fost comparate cu cele ale pacienţilor cu arteriopatie cronică obliterantă aterosclerotică a membrelor inferioare. Am investigat impactul nivelelor bazale asupra incidenţei evenimentelor ischemice nou apărute în evoluţia de durată. Rezultate: Au fost luaţi în studiu 91 pacienţi cu manifestări clinice ale aterosclerozei, 59 cu cardiopatie ischemică şi 32 cu arteriopatie cronică obliterantă a membrelor inferioare. În grupul pacienţilor cu cardiopatie ischemică, comparativ cu cel al pacienţilor cu arteriopatie cronică obliterantă a membrelor inferioare, nivelele plasmatice ale leptinei au fost semnificativ mai crescute $(2882.02 \pm 368.57 \mathrm{pg} / \mathrm{ml} \mathrm{vs} 1025.56 \pm$ $232.28 \mathrm{pg} / \mathrm{ml} ; \mathrm{p}<0.001)$, cele ale resistinei semnificativ mai scăzute $(13.15 \pm 0.83 \mathrm{ng} / \mathrm{ml} \mathrm{vs} 17.76 \pm 2.13 \mathrm{ng} / \mathrm{ml}$; $p=0.02)$ şi nu s-au constatat diferenţe privind nivelele adiponectinei şi ale TNF- $\alpha$. Nivele plasmatice ale leptinei s-au corelat cu indicele de masă corporală în ambele grupe de pacienţi. 45 pacienţi (49,5\%) au fost reinternaţi în următorii 2 ani. Intr-o analiză multivariabilă numai resistina $\geq 15 \mathrm{ng} / \mathrm{ml}, \mathrm{HR}=1.8829,95 \%$ CI 1.0490- 3.3797, $p=0.034$ şi presiunea arterială diastolică $\geq 85 \mathrm{mmHg}, H R=2.0927,95 \%$ CI 1.0782- 4.0616, $p=0.0299$ au fost independent asociate cu noi evenimente cardiovasculare. Concluzii: La pacienţi cu ateroscleroză clinic manifestă nivelele plasmatice ale resistinei pot prezice noi evenimente ischemice.

Cuvinte cheie: resistina, leptina, cardiopatie ischemică, arteriopatie cronică obliterantă a membrelor inferioare

Received: $18^{\text {th }}$ November 2013; Accepted: $9^{\text {th }}$ March 2014; Published: $14^{\text {th }}$ March 2014.

\section{Introduction}

A number of cytokines and adipokines secreted by the adipose tissue may influence the vessels wall directly. Resistin was discovered in 2001. Initially characterized in mice, resistin was found to be secreted by adipocytes and was named for the insulin resistance induced in animal studies (1). Resistin, also known as adipose tissue-specific secretory factor (ADSF) or $\mathrm{C} /$ EBP-epsilon-regulated myeloid-specific secreted cysteine-rich protein (XCP1), is a cysteine-rich adipose-derived peptide hormone that in humans is encoded by the RETN gene (2). The molecule is primarily expressed in circulating monocytes and macrophages and is strongly correlated with inflammatory markers in humans.

Resistin has been shown to increase transcriptional events, leading to an increased expression of several pro-inflammatory cytokines including IL-1, IL-6, IL-12 and TNF- $\alpha$ (3-7) and induced expression and secretion of all of proinflammatory mediators involved in the activation of nuclear transcription factor kappa B (NF-kB) through activation of protein kinase $\mathrm{C}$ (PKC), 1,4,5 inositol triphosphate (IP3) and the mobilezation of intracellular calcium $(\mathrm{Ca} 2+)$
$(8,9)$. Resistin upregulates ICAM1, VCAM1 and CCL2, involved in leukocyte recruitment to sites of infection (10).

The role of resistin in the metabolic syndrome is controversial. Some investigations have reported that resistin levels correlate with insulin resistance and obesity $(1,11,12)$, while others failed to observe any correlation with metabolic markers. As compared to controls, in subjects with metabolic syndrome no significant differences in resistin levels were observed (1315). Some studies revealed gender-differences, some of these correlations are present being in women, but absent in men $(13,16,17)$.

It has been reported that resistin causes a marked increase in the generation of reactive oxygen species and thereby decreases expression of endothelial nitric oxide synthase in endothelial cells $(18,19)$.

Resistin has been noted to play a vital role in increasing the level of VLDL and LDL in obese persons (20-22), it induces increases in MCP-1 and sVCAM-1 expression in vascular endothelial cells, promotes the proliferation of VSMC that occurs through both ERK 1/2 and Akt signalling pathways, which suggest a possible mechanism 
that contributes to atherogenesis (10, 23-26). Resistin promotes foam cell formation via dysregulation of scavenger receptors (SR-A) and ATP-binding cassette transporter-A1 (ABCA1) through PPAR gamma $(26,27)$.

Patients with acute coronary syndrome (ACS) had significantly higher resistin levels than those without $\operatorname{ACS}(28,29)$ and the follow-up (mean of 83.4 months) showed that the resistin level was an independent predictor of ACS.

The prognostic role of adipokines in atherosclerosis is not well established. The aim of this study was to compare the baseline plasma levels of adiponectin, resistin, leptin and TNF- $\alpha$ in patients with coronary artery disease (CAD) and peripheral artery disease (PAD). Also, we investigated the impact of baseline plasma levels of adiponectin, resistin, leptin and TNF- $\alpha$ on the incidence of the new ischemic cardiovascular events.

\section{Materials and methods}

Subjects. 91 patients with clinical symptoms of atherosclerosis, in two different areas, lower extremity occlusive disease and coronary artery disease, hospitalized in the County Emergency Clinical Hospital from Cluj-Napoca, were included in study between 2008-2009. We followed up the readmissions between 2009 and 2011. The primary endpoint of the study was the readmission of the patient. We defined a cardiovascular event the readmission for nonfatal myocardial infarction, heart failure, or critical limb ischemia.

The peripheral arterial occlusive disease was defined clinically, by ankle-brachial index $<0.9$, by Doppler and angiographic exams. The coronary artery disease was investigated clinically, by electrocardiogram, echocardiography and in some cases by coronarography. Clinical variables were analyzed.
Methods. Blood samples were obtained in a non-fasting state. After $10 \mathrm{~min}$ of rest in the supine position, the blood samples were collected from the antecubital vein. Peripheral blood was drawn from each patient within $2 \mathrm{~h}$ from admission. Serum and plasma were immediately separated by centrifugation and stored at $-80^{\circ}$ until analysis.

Plasma levels of adiponectin, leptin, resistin, and TNF- $\alpha$ were measured by commercially available ELISA, quantikine reagents (R\&D System) according to manufacturer suggestions. Regarding the sensitivity of resistin assay, the analitical limit of detection was $0.055 \mathrm{ng} / \mathrm{ml}$; intra- assay coefficients of variation (\%) were 3.8- 5.3 and inter-assay coefficients of variation (\%) were 7.8-9.2. For adiponectin assay, the analytical limit of detection was $0.891 \mathrm{ng} /$ $\mathrm{ml}$; intra-assay $\mathrm{CV}(\%)$ were $2.5-4.7$ and inter assay CV (\%) were 5.9- 6.9. For leptin assay, the analytical limit of detection was $7.8 \mathrm{pg} / \mathrm{ml}$; intra-assay $\mathrm{CV}(\%)$ were $3.2-3.3$ and inter assay CV (\%) were 3.5-5.4. For TNF- $\alpha$ assay, the analytical limit of detection was $5.5 \mathrm{pg} / \mathrm{ml}$; intra-assay $\mathrm{CV}(\%)$ were $4.2-5.2$ and inter-assay CV (\%) were 4.6-7.4.

All patients participated voluntarily and each subject included in the study signed a written informed consent for the participation in the study approved by the Local Ethics Committee.

Exclusion criteria were active infectious disease, neoplasia, acute coronary syndrome, strokes, hepatic or renal failure, severe heart failure.

Statistical analysis. Estimated time to readmission was performed by Kaplan-Meier method and differences between Kaplan-Meier curves were evaluated by log rank test (30).

Comparison of means, where it was required, was done by Student Test and comparison of the percentage by chi-square test. If the number of subjects was small (groups under 5 or under 5\%) Yates corrections were used (30). 
For all the tests used the p-value under 0.05 was considered significant. Confidence interval values were also calculated with the threshold of 0.05 .

For the multivariate Cox model analysis the step backward algorithm was chosen, starting from a maximal model and eliminating all variables that were above the significance threshold of 0.05 .

As a statistical software we used Excel 2003 and MEDCALC version 9.6.

\section{Results}

In 91 patients hospitalized for clinical symptoms of atherosclerosis, the minimum, maximum and median age were $36,84,67$ and the ratio men / women was $56 / 35=61.54 \% / 38.46 \%$.

There was a balanced value on the gender distribution for CAD. In PAD men dominated the category. As compared with PAD, only the body mass index and the cholesterol were significantly higher in the CAD group $(\mathrm{p}<0.01$ and $\mathrm{p}<0.05$ respectively) (Table $I$ ).

In terms of numerical variables only resistin and leptin were statistically significant. In patients with CAD as compared with PAD baseline plasma levels of leptin were significantly increased $(2882.02 \pm 368.57 \mathrm{pg} / \mathrm{ml}$ vs 1025.56 $\pm 232.28 \mathrm{pg} / \mathrm{ml} ; \mathrm{p}<0.001)$, plasma levels of resistin were significantly decreased $(13.15 \pm 0.83$ $\mathrm{ng} / \mathrm{ml}$ vs $17.76 \pm 2.13 \mathrm{ng} / \mathrm{ml} ; \mathrm{p}=0.02)$ and no differences in plasma levels of adiponectin and TNF- $\alpha$ were found (Table II).

A significant correlation between BMI and plasma levels was found only for leptin, irrespective of group (PAD: $\mathrm{r}=0.395 ; \mathrm{p}<0.02$; 95\%CI $0.08607-0.6345$, respectively CAD: $r=$ $0.392 ; \mathrm{p}<0.00395 \%$ CI $0.1507-0.5887)$. No other correlation between the clinical characteristics and plasma levels of resistin, leptin, adiponectin and TNF- $\alpha$ were found.

Table I. Clinical and epidemiological characteristics of the study groups

\begin{tabular}{|c|c|c|c|c|c|}
\hline & Disease & women & men & total & $\mathbf{p}$ \\
\hline \multirow{2}{*}{ Gender distribution } & PAD & $\begin{array}{c}5 \\
(15.62 \%)\end{array}$ & $\begin{array}{c}27 \\
(84.38 \%) \\
\end{array}$ & 32 & \multirow{2}{*}{$\mathrm{p}<0.01$} \\
\hline & CAD & $\begin{array}{c}30 \\
(50.85 \%) \\
\end{array}$ & $\begin{array}{c}29 \\
(49.15 \%) \\
\end{array}$ & 59 & \\
\hline & & Mean & Median & Std. Err. & \\
\hline \multirow{2}{*}{ Age (y) } & PAD & 61.75 & 64.5 & 2.19 & \multirow{2}{*}{0.11} \\
\hline & CAD & 66.05 & 69 & 1.53 & \\
\hline \multirow{2}{*}{$\begin{array}{l}\text { Systolic blood pressure (SBP) } \\
\text { (mmHg) }\end{array}$} & PAD & 135.00 & 135 & 2.52 & \multirow{2}{*}{0.07} \\
\hline & CAD & 128.32 & 130 & 2.32 & \\
\hline \multirow{2}{*}{$\begin{array}{l}\text { Diastolic blood pressure (DBP) } \\
(\mathrm{mmHg})\end{array}$} & PAD & 76.88 & 80 & 1.52 & \multirow{2}{*}{0.47} \\
\hline & CAD & 75.37 & 70 & 1.29 & \\
\hline \multirow{2}{*}{$\begin{array}{l}\text { BMI (body mass index) } \\
\left(\mathrm{kg} / \mathrm{m}^{2}\right)\end{array}$} & PAD & 24.76 & 25.23 & 4.72 & \multirow{2}{*}{0.01} \\
\hline & $\mathrm{CAD}$ & 28.02 & 27.40 & 5.55 & \\
\hline \multirow{2}{*}{ Fasting plasma glucose $(\mathrm{mg} / \mathrm{dL})$} & PAD & 121.32 & 109 & 49.16 & \multirow{2}{*}{0.53} \\
\hline & CAD & 128.92 & 108 & 55.82 & \\
\hline \multirow{2}{*}{$\begin{array}{l}\text { Total cholesterol } \\
(\mathbf{m g} / \mathbf{d L})\end{array}$} & PAD & 233.14 & 226 & 69.97 & \multirow{2}{*}{0.05} \\
\hline & CAD & 196.81 & 192 & 74.57 & \\
\hline
\end{tabular}


Table II. Plasma levels of adipocytokines in patients with PAD and CAD

\begin{tabular}{|c|c|c|c|c|c|c|c|}
\hline & Disease & Min & Max & Mean & Median & Std. err. & p \\
\hline \multirow{2}{*}{ Adiponectin ng/ml } & PAD & 336 & 4666 & 1764.81 & 1603.5 & 181.94 & \multirow{2}{*}{0.45} \\
\hline & CAD & 290 & 5999 & 1974.05 & 1707 & 178.45 & \\
\hline \multirow{2}{*}{$\begin{array}{l}\text { Resistin } \\
\text { ng/ml }\end{array}$} & PAD & 5.5 & 65 & 17.76 & 16.25 & 2.13 & \multirow{2}{*}{0.02} \\
\hline & CAD & 4 & 31 & 13.15 & 11 & 0.83 & \\
\hline \multirow{2}{*}{$\begin{array}{l}\text { Leptin } \\
\mathrm{pg} / \mathrm{ml}\end{array}$} & PAD & 15 & 5305 & 1025.56 & 527.5 & 232.28 & \multirow{2}{*}{$<0.01$} \\
\hline & CAD & 31 & 13844 & 2882.02 & 2047 & 368.57 & \\
\hline \multirow{2}{*}{$\begin{array}{l}\text { TNF alfa } \\
\mathrm{ng} / \mathrm{ml}\end{array}$} & PAD & 0.3 & 169 & 25.14 & 2.25 & 6.56 & \multirow{2}{*}{0.49} \\
\hline & CAD & 0.3 & 279 & 31.71 & 22 & 6.07 & \\
\hline
\end{tabular}

During the two years we recorded 45 readmissions (49.5\%). Regarding the time from discharge to the first readmission no significant differences were obtained concerning the gender $(\mathrm{p}=0.14)$, although women had a disease-free survival of $60 \%$ and men only $46 \%$.

Type of artery disease (CAD, PAD) did not induce significant differences in time-to-readmission analysis $(\mathrm{p}=0.20)$ (Figure 1$)$.

For numeric variables adiponectin, leptin, resistin, TNF-alpha, age, SBP and DBP we have chosen as cut-off points the corresponding values that provide the lowest p. Figure 2 represents p-values choosing as cut-off one by one all the values that existed in our data and that generates at least 10 subjects per group. Under the threshold of significance 0.05 we have p-values only for leptin $(2000 \mathrm{pg} / \mathrm{ml})$, resistin $(15 \mathrm{ng} / \mathrm{ml})$ and DBP $(85 \mathrm{mmHg})$.

Figures 3, 4 and 5 show the Kaplan-Meier curves for these cut-off values.

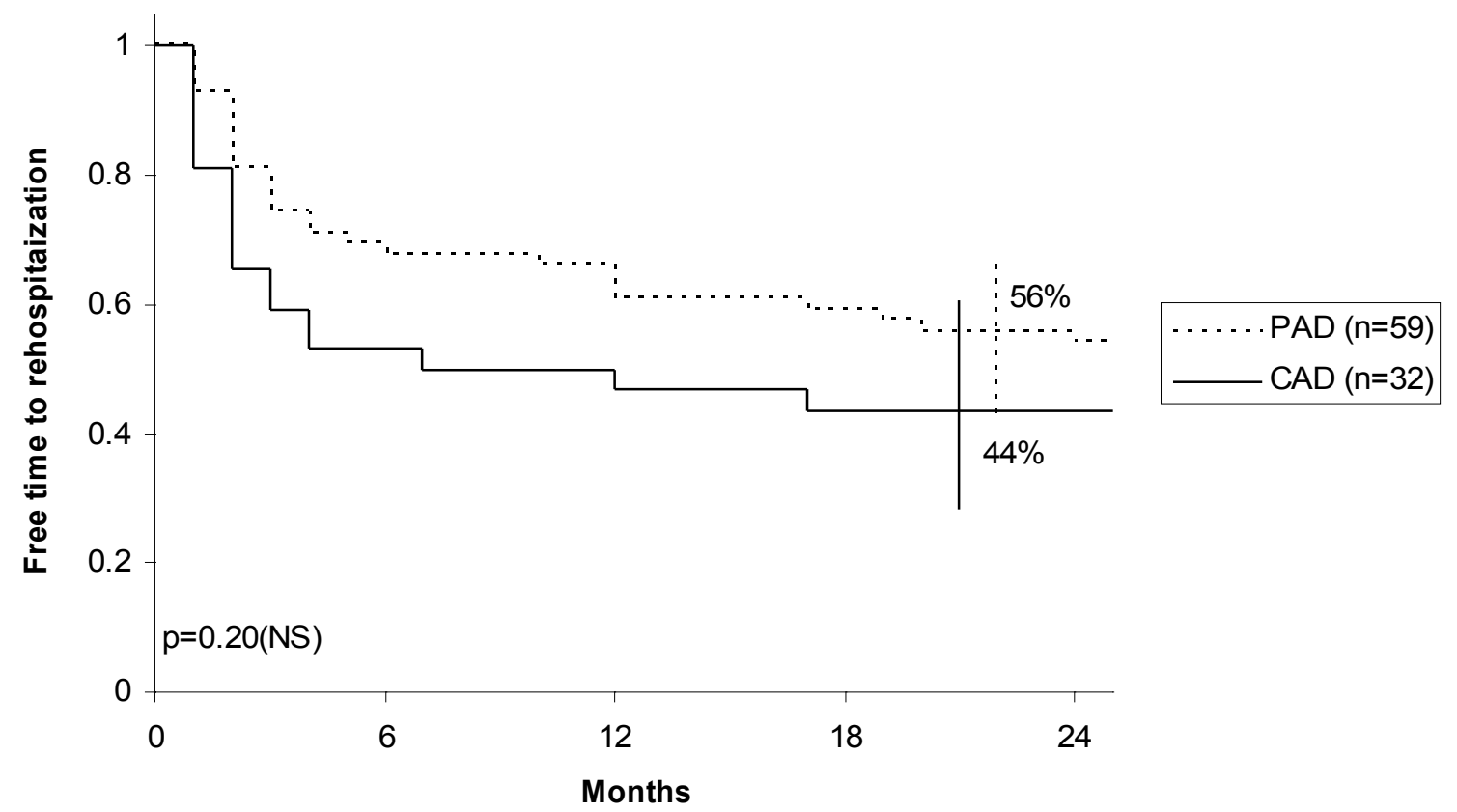

Figure1. Free time to rehospitalization in the study groups 

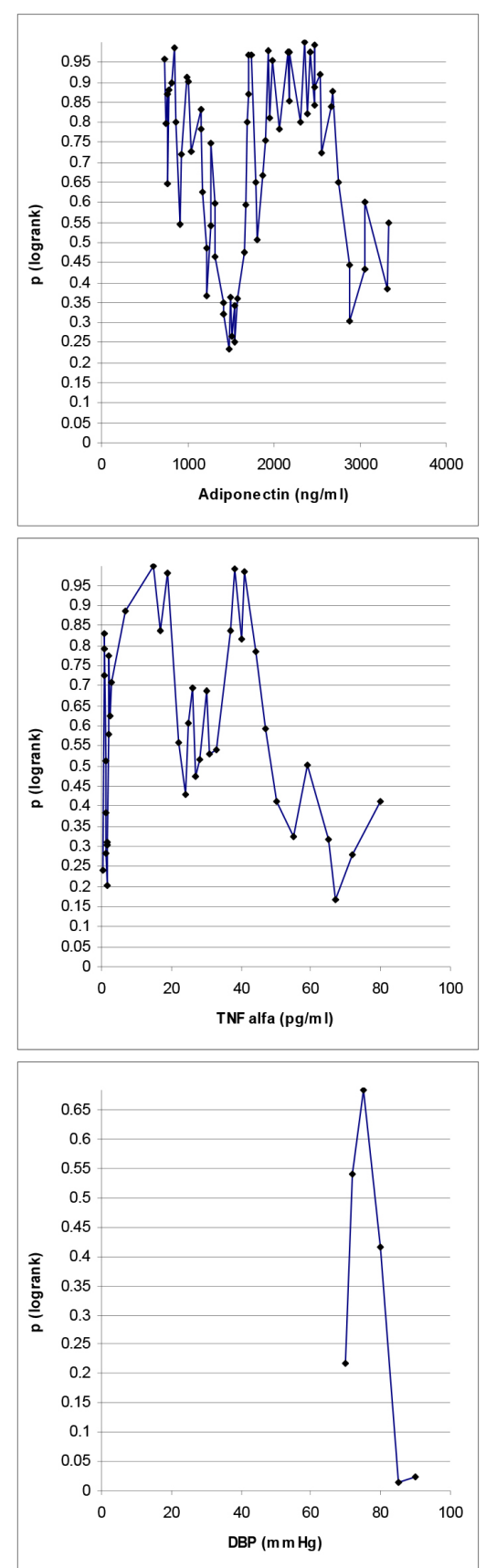


Figure 2. The p values taking as cut off all observed data values so that we have groups of at least 10 subjects

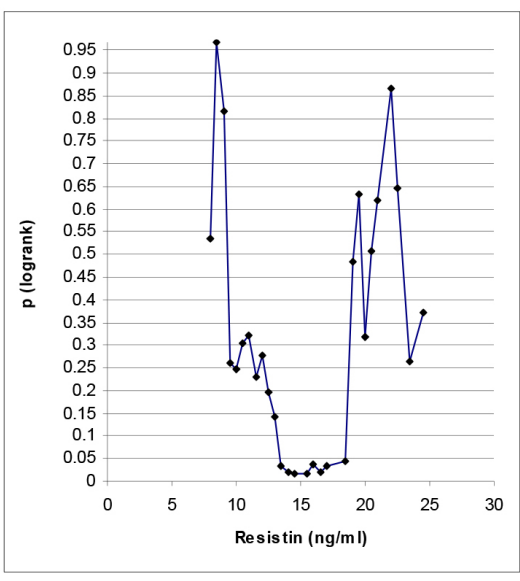

For multivariate analysis we chose the numerical variables that had statistical significance with cut-off points in Figure 3, 4 and 5 , to which we added gender and arterial disease type (CAD, PAD), due to the strong links highlighted in Table $I$ and $I I$, even when $\mathrm{p}$-values were higher than the threshold of significance $(\mathrm{p}=0.14$ and $\mathrm{p}=0.20)$.

We performed a Cox model analysis by the step backward algorithm (at each step we removed the variable with the highest p-value until all the remaining variables had the $p$-value below the threshold of significance).

The following were excluded in this order: artery disease type (CAD, PAD), gender and leptin, and only DBP $85 \mathrm{mmHg}$ threshold value and resistin value threshold of $15 \mathrm{ng} / \mathrm{ml}$ remained in the model.

Table III represents the final results of the Cox model with the significant variables. 


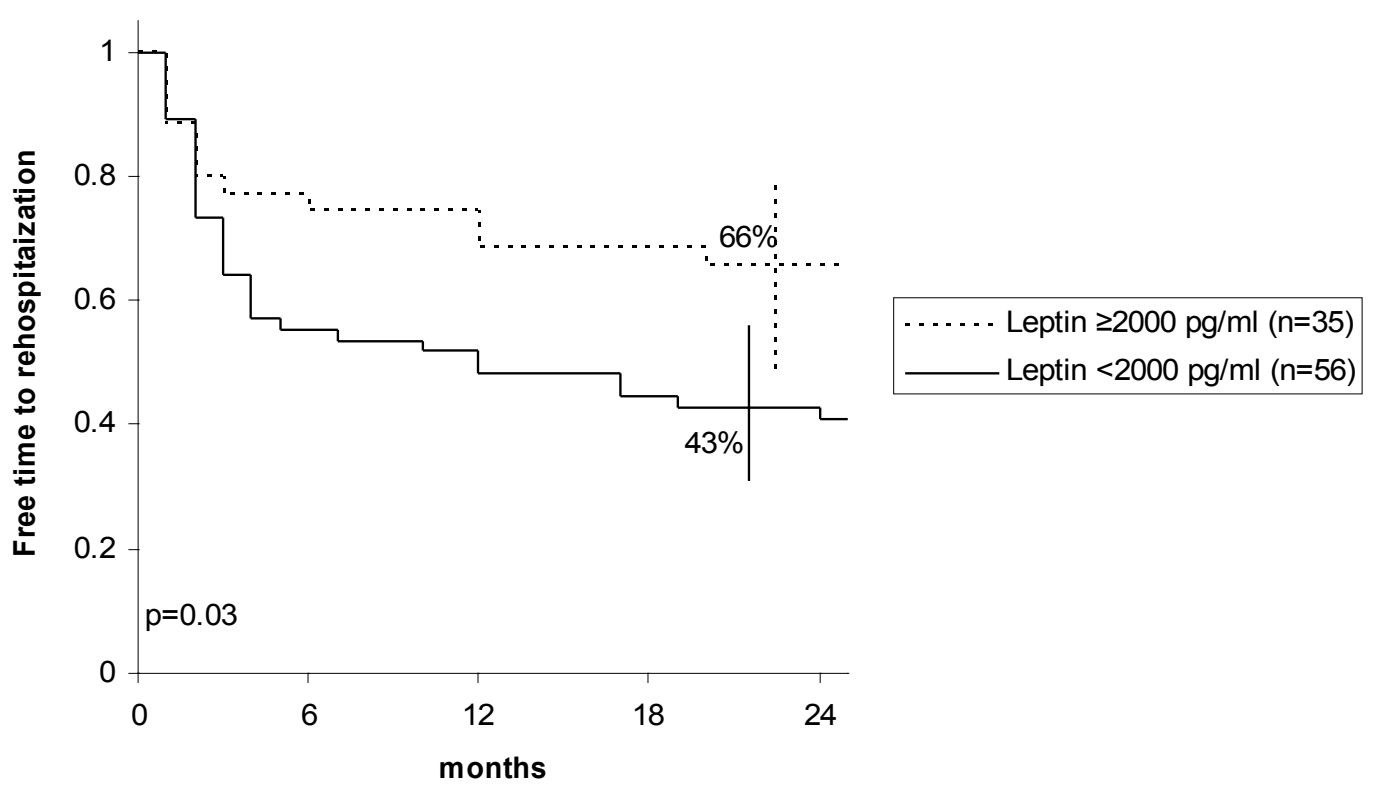

Figure. 3. Free time to rehospitalization in relation to plasma leptin levels

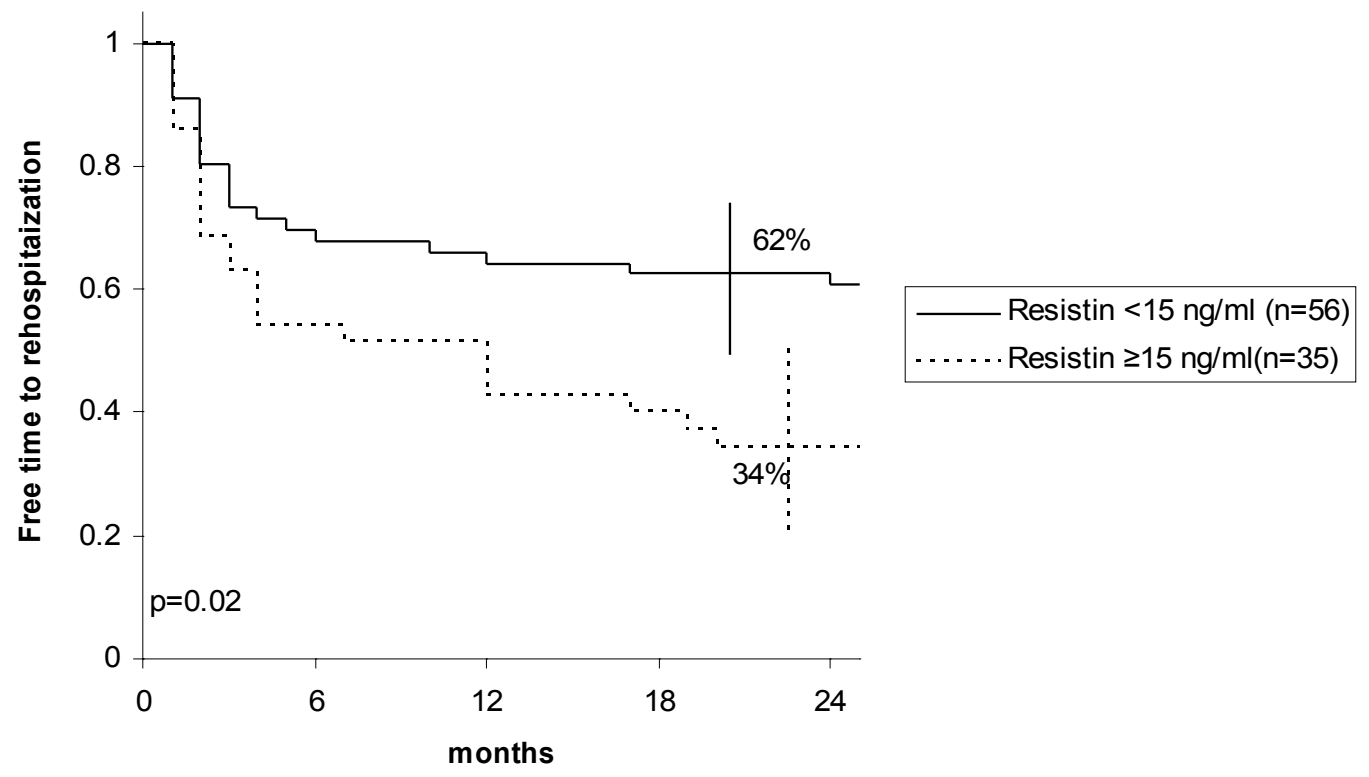

Figure. 4. Free time to rehospitalization in relation to resistin plasma levels

Figure 6 contains the Kaplan-Meier curves for all scores derived from Cox model. Legend explains the categories of patients according to the score.
Due to fact that patients with DBP $<85$ $\mathrm{mmHg}$ and resistin $\geq 15 \mathrm{ng} / \mathrm{ml}$ and patients with $\mathrm{DBP} \geq 85 \mathrm{mmHg}$ and resistin $<15 \mathrm{ng} / \mathrm{ml}$ present closer scores implying closer risks we decide to 


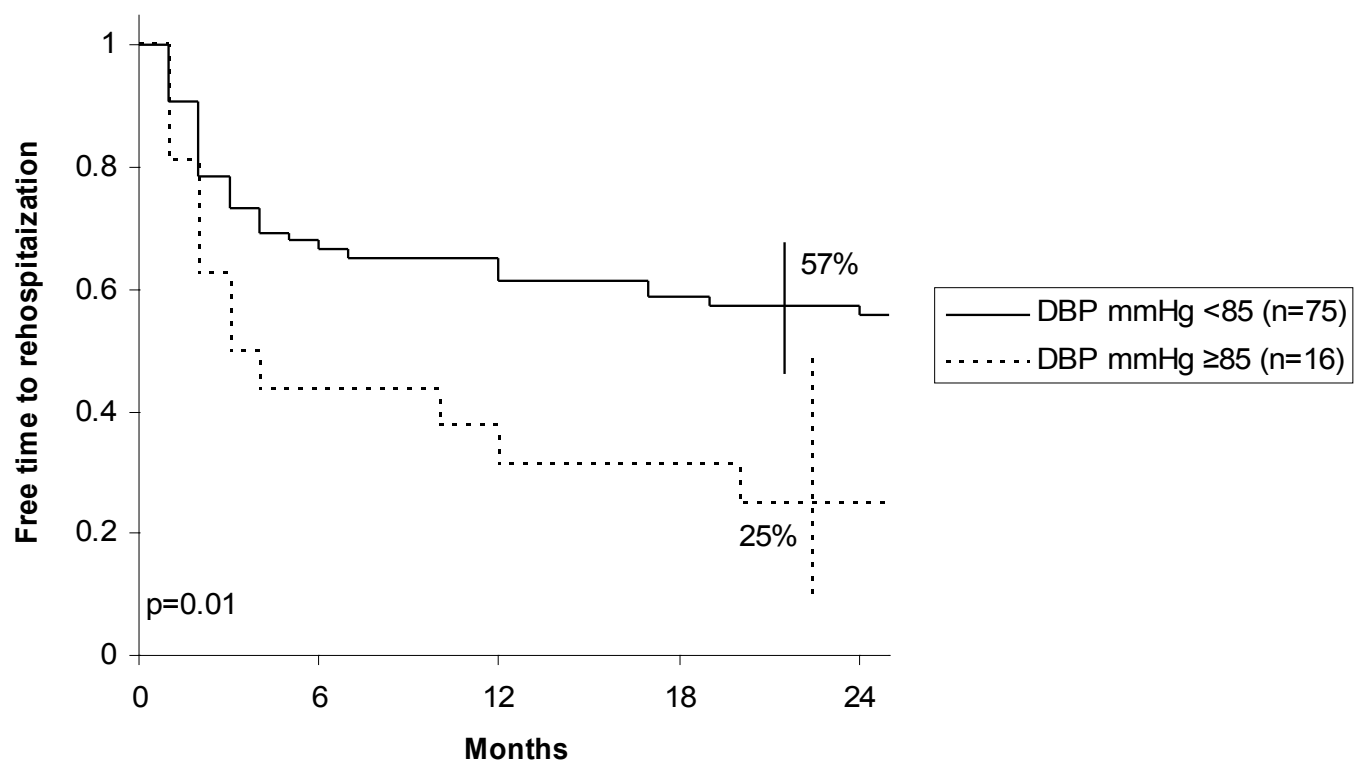

Figure. 5. Free time to rehospitalization in relation to DBP

put together both categories and we generated a new simplified score with three values: 0 if both resistine and DBP were favorable, 1 if one from resistin and DBP is favorable and the other is unfavorable, 2 if both DBP and resistin are unfavorable (Figure7).

\section{Discussion}

As compared with PAD, patients included in the CAD group were older, $(66.05 \pm 1.53$ years vs $61.75 \pm 2.19$ years; $p=0.11)$. In our study BMI and the total cholesterol were significantly higher in patients with $\mathrm{CAD}$ as compared with PAD ( $p<0.01$ and $p<0.05$ respectively).

A significant correlation between BMI and plasma levels was found only for leptin, irrespective of group. Our findings confirm other studies on BMI - resistin and BMI-leptin rela- tionships $(13,31-33)$. In the study by de Luis (13) resistin concentrations were not related to BMI or other index of obesity and resistin was correlated only with total fat mass measured by bioimpedance and this relation persisted with multivariate analysis only in women. These data support resistin's primary role in inflammatory rather than metabolic pathways.

Leptin is primarily synthesized and released by mature adipocytes. Leptin circulating levels are highly correlated with BMI $(32,33)$. Leptin is a hormone with pleiotrophic actions in multiple organ systems. Human studies on leptin and $\mathrm{CAD}$ have reported conflicting results. In populations without CAD, few studies have shown leptin to be associated with increased risk of incident CAD, while others found no association. Other authors have reported a protective associ-

Table III. Summary of the Cox model

\begin{tabular}{lccccc}
\hline Variable & Coefficients & Std. err. & p & Risk & 95\% CI of risk \\
\hline $\mathrm{DBP}<85 \mathrm{~mm} \mathrm{Hg}$ vs $\geq 85 \mathrm{~mm} \mathrm{Hg}$ & 0.7384 & 0.3401 & 0.0299 & 2.0927 & 1.0782 to 4.0616 \\
\hline Resistin $<15 \mathrm{ng} / \mathrm{ml} \mathrm{vs} \geq 15 \mathrm{ng} / \mathrm{ml}$ & 0.6328 & 0.3 & 0.0349 & 1.8829 & 1.0490 to 3.3797 \\
\hline
\end{tabular}




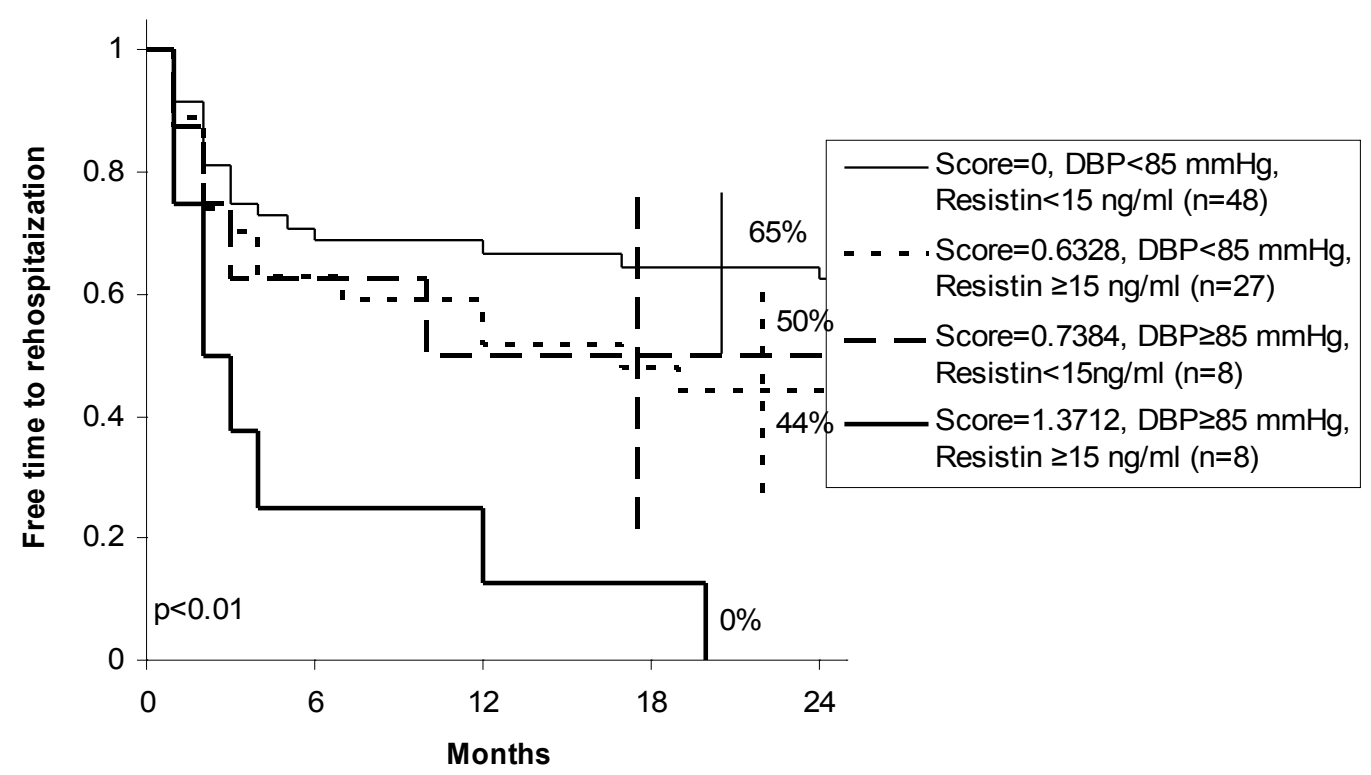

Figure 6. Free time to rehospitalization using the score resulting from Cox model

ation of leptin with decreased CV mortality in populations with diabetes (34) and chronic kidney disease (35). A recent meta-analysis of these studies has concluded that there is a modest association of high leptin with the risk of incident CAD (36). Ku et al (37) found an inverse asso- ciation between leptin and CV events in patients with chronic CAD.

In our study a different pattern of plasma levels of resistin and leptin in patients with PAD or CAD was found. As compared with $\mathrm{CAD}$, plasma levels of resistin were significatly

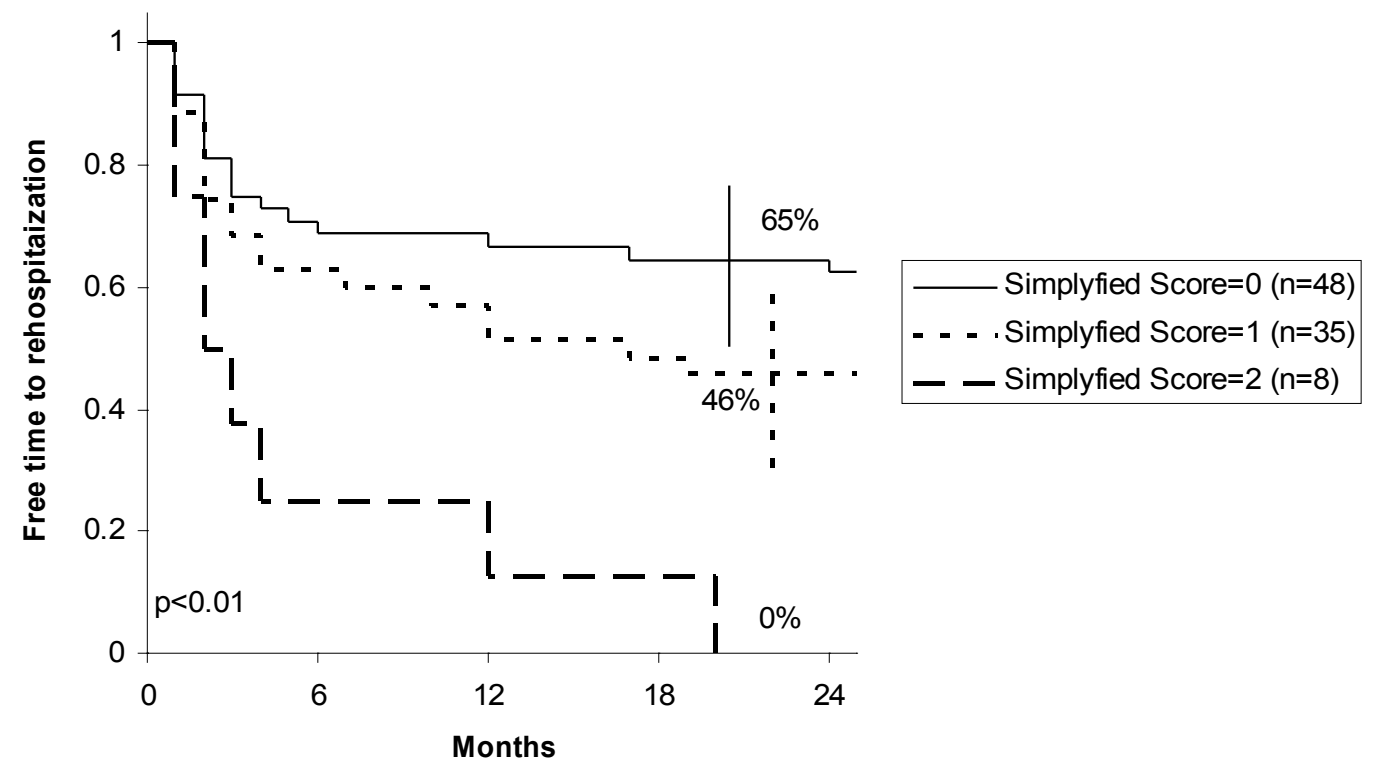

Figure 7. Free time to rehospitalization using the simplified score 
higher in patients with PAD $(17.76 \pm 2.13 \mathrm{ng} / \mathrm{ml}$ vs $13.15 \pm 0.83 \mathrm{ng} / \mathrm{ml}$; $\mathrm{p}<0.02$ ). Plasma levels of leptin were significatly lower in PAD as compared with CAD $(1025.56 \pm 232.28 \mathrm{pg} / \mathrm{ml}$ vs $2882.04 \pm 368.57 \mathrm{pg} / \mathrm{ml} \mathrm{p}<0.02)$. No significant differences between plasma levels of adiponectin and TNF- $\alpha$ were found.

Regarding the time from discharge to the first readmission no significant differences were obtained concerning the gender, although women had a disease-free survival of $60 \%$ and men only $46 \%$. The type of artery disease did not induce significant differences in time to readmission analysis. In our study plasma levels of resistin were significantly higher and leptin was significantly lower in PAD and in this group a significant higher number of patients were free of readmission as compared with CAD. In the simple Cox model, the variables associated with prognosis were leptin $(2000 \mathrm{pg} / \mathrm{ml})$, resistin (15 $\mathrm{ng} / \mathrm{ml}$ ) and DBP (85 mmHg). Using a multivariate Cox model the only variable positively correlated with readmissions was resistin $\geq 15 \mathrm{ng} / \mathrm{ml}$ and the $\mathrm{DBP} \geq 85 \mathrm{mmHg}$.

Our results regarding the prognostic value of resistin confirm other studies. Owens et al. (38) demonstrated the role of resistin in predicting lower extremity artery disease. In a prospective longitudinal study they evaluated patients undergoing lower extremity bypass surgery and showed that patients with critical limb ischemia and diabetes had elevated levels of resistin and high sensitivity CRP. Resistin was the only predictor associated with amputation-free survival in the diabetic patients (38). The combination of high resistin and the presence of either diabetes or hypertension increased the risk of ischemic stroke (39). In another study, circulating levels of resistin, but not of adiponectin or leptin, were associated with an increased risk of incident ischemic stroke in postmenopausal women (40).
The role of resistin as a risk factor for myocardial infarction was also investigated (41).

Despite its involvement in inflammatory pathways, the role of resistin as an independent risk factor for cardiovascular events and mortality is controversial. In patients with stable multivessel coronary artery disease, Krecki et al. (42) found that elevated plasma resistin was a strong, independent predictive factor for the occurrence of major adverse cardiac and cerebrovascular events. Although in some studies plasma levels of resistin were correlated with mortality (4345 ), in most prospective clinical studies resistin fails to appear as an independent risk factor for cardiovascular events and mortality (46-49).

\section{Conclusions}

A different pattern of plasma levels of resistin and leptin in patients with coronary artery disease and peripheral arterial occlusive disease was found.

In patients with CAD as compared with PAD baseline plasma levels of leptin were significantly increased and plasma levels of resistin were significantly decreased.

In patients with coronary artery disease and peripheral arterial occlusive disease no significant differences between plasma levels of adiponectin and TNF- $\alpha$ were found.

In multivariate analysis resistin $\geq 15 \mathrm{ng} / \mathrm{ml}$ and the DBP $\geq 85 \mathrm{mmHg}$ predicts rehospitalization.

\section{Acknowledgements}

The present study was partially supported by a research Grant GAR 135 of the Romanian Academy as well as by a Programme 4 Partnerships in Priority Areas Grant 2007-2013, coordinated by the National Center for Programme Management, Grant 61049. 


\section{References}

1. Steppan CM, Bailey ST, Bhat S, Brown EJ, Banerjee RR, Wright CM, et al. The hormone resistin links obesity to diabetes. Nature. 2001;409(6818):307-12. DOI: $10.1038 / 35053000$

2. Wang H, Chu WS, Hemphill C, Elbein SC. Human resistin gene: molecular scanning and evaluation of association with insulin sensitivity and type 2 diabetes in Caucasians. J Clin Endocrinol Metab. 2002;87(6):25204. DOI: $10.1210 /$ jcem.87.6.8528 DOI: $10.1210 /$ jc.87.6.2520

3. Adeghate E. An update on the biology and physiology of resistin. Cell Mol Life Sci. 2004;61(19-20):2485-96. DOI: $10.1007 / \mathrm{s} 00018-004-4083-2$

4. Stumvoll M, Haring H. Resistin and adiponectin--of mice and men. Obes Res. 2002;10(11):1197-9. DOI: 10.1038/oby.2002.162

5. Vendrell J, Broch M, Vilarrasa N, Molina A, Gomez JM, Gutierrez C, et al. Resistin, adiponectin, ghrelin, leptin, and proinflammatory cytokines: relationships in obesity. Obes Res. 2004;12(6):962-71. DOI: 10.1038/ oby. 2004.118

6. Milan G, Granzotto M, Scarda A, Calcagno A, Pagano $\mathrm{C}$, Federspil G, et al. Resistin and adiponectin expression in visceral fat of obese rats: effect of weight loss. Obes Res. 2002;10(11):1095-103. DOI: 10.1038/ oby. 2002.149

7. Silswal N, Singh AK, Aruna B, Mukhopadhyay S, Ghosh S, Ehtesham NZ. Human resistin stimulates the pro-inflammatory cytokines TNF-alpha and IL-12 in macrophages by NF-kappaB-dependent pathway. Biochem Biophys Res Commun. 2005;334(4):1092-101. DOI: 10.1016/j.bbrc.2005.06.202

8. Barnes KM, Miner JL. Role of resistin in insulin sensitivity in rodents and humans. Curr Prot Peptide Sci. 2009;10(1):96-107. DOI: $10.2174 / 138920309787315239$

9. Kaser S, Kaser A, Sandhofer A, Ebenbichler CF, Tilg $\mathrm{H}$, Patsch JR. Resistin messenger-RNA expression is increased by proinflammatory cytokines in vitro. Biochem Biophys Res Commun. 2003;309(2):286-90. DOI: 10.1016/j.bbrc.2003.07.003

10. Verma S, Li SH, Wang CH, Fedak PW, Li RK, Weisel $\mathrm{RD}$, et al. Resistin promotes endothelial cell activation: further evidence of adipokine-endothelial interaction. Circulation. 2003;108(6):736-40. DOI: 10.1161/01. CIR.0000084503.91330.49

11. Steppan CM, Lazar MA. The current biology of resistin. J Intern Med. 2004;255(4):439-47. DOI: 10.1111/j.1365-2796.2004.01306.x

12. Azuma K, Katsukawa F, Oguchi S, Murata M, Yamazaki H, Shimada A, et al. Correlation between serum resistin level and adiposity in obese individuals. Obes Res. 2003;11(8):997-1001. DOI: 10.1038/oby.2003.137
13. de Luis DA, Gonzalez Sagrado M, Conde R, Aller R, Izaola O, Perez Castrillon JL, et al. Relation of resistin levels with cardiovascular risk factors and insulin resistance in non-diabetes obese patients. Diabetes Res Clin Prac. 2009;84(2):174-8. DOI: 10.1016/j.diabres.2009.01.017

14. Pfutzner A, Langenfeld M, Kunt T, Lobig M, Forst T. Evaluation of human resistin assays with serum from patients with type 2 diabetes and different degrees of insulin resistance. Clin Lab. 2003;49(11-12):571-6.

15. Iqbal N, Seshadri P, Stern L, Loh J, Kundu S, Jafar T, et al. Serum resistin is not associated with obesity or insulin resistance in humans. Eur Rev Med Pharmacol Sci. 2005;9(3):161-5.

16. Chen CC, Li TC, Li CI, Liu CS, Wang HJ, Lin CC. Serum resistin level among healthy subjects: relationship to anthropometric and metabolic parameters. Metabolism. 2005;54(4):471-5. DOI: 10.1016/j.metabol.2004.10.015

17. Pischon T, Bamberger CM, Kratzsch J, Zyriax BC, Algenstaedt $\mathrm{P}$, Boeing $\mathrm{H}$, et al. Association of plasma resistin levels with coronary heart disease in women. Obes Res. 2005;13(10):1764-71. DOI: 10.1038/ oby. 2005.215

18. Chen C, Jiang J, Lu JM, Chai H, Wang X, Lin PH, et al. Resistin decreases expression of endothelial nitric oxide synthase through oxidative stress in human coronary artery endothelial cells. Am J Physiol Hear Cir Physiol. 2010;299(1):H193-201. DOI: 10.1152/ ajpheart.00431.2009

19. Kougias P, Chai H, Lin PH, Lumsden AB, Yao Q, Chen C. Adipocyte-derived cytokine resistin causes endothelial dysfunction of porcine coronary arteries. J Vasc Surg. 2005;41(4):691-8. DOI: 10.1016/j. jvs.2004.12.046

20. Burnett MS, Lee CW, Kinnaird TD, Stabile E, Durrani $\mathrm{S}$, Dullum MK, et al. The potential role of resistin in atherogenesis. Atherosclerosis. 2005;182(2):241-8. DOI: $10.1016 /$ j.atherosclerosis.2005.02.014

21. Xu W, Yu L, Zhou W, Luo M. Resistin increases lipid accumulation and CD36 expression in human macrophages. Biochem Biophys Res Commun. 2006;351(2):376-82. DOI: 10.1016/j.bbrc.2006.10.051

22. Rizkalla J, Melone M, Zhao A, Rashid S. The pathophysiological role of resistin in impaired lipoprotein metabolism in obesity. Circulation. 2009;120:S529.

23. Calabro P, Samudio I, Willerson JT, Yeh ET. Resistin promotes smooth muscle cell proliferation through activation of extracellular signal-regulated kinase $1 / 2$ and phosphatidylinositol 3-kinase pathways. Circulation. 2004;110(21):3335-40. DOI: 10.1161/01. CIR.0000147825.97879.E7

24. Cohen G, Horl WH. Resistin as a cardiovascular and atherosclerotic risk factor and uremic toxin. Semin Dial. 2009;22(4):373-7. DOI: 10.1111/j.1525139X.2009.00583.x 
25. Kawanami D, Maemura K, Takeda N, Harada T, Nojiri $\mathrm{T}$, Imai $\mathrm{Y}$, et al. Direct reciprocal effects of resistin and adiponectin on vascular endothelial cells: a new insight into adipocytokine-endothelial cell interactions. Biochem Biophys Res Commun. 2004;314(2):415-9. DOI: 10.1016/j.bbrc.2003.12.104

26. Sharma R, Kumar C, Gangwani S, Singh Sugga G, Rana AC. Resistin and cardiovascular disorder. Afr J of Pharm Pharmacol. 2011;5(1):5.

27. Lee TS, Lin CY, Tsai JY, Wu YL, Su KH, Lu KY, et al. Resistin increases lipid accumulation by affecting class A scavenger receptor, CD36 and ATP-binding cassette transporter-A1 in macrophages. Life Sci. 2009;84(34):97-104. DOI: 10.1016/j.lfs.2008.11.004

28. Li L, Han JL, Mao JM, Guo LJ, Gao W. Association between serum resistin level and cardiovascular events in postmenopausal women with acute coronary syndrome undergoing percutaneous coronary intervention. Clin Med J. 2013;126(6):1058-62.

29. Erer HB, Sayar N, Guvenc TS, Aksaray S, Yilmaz H, Altay S, et al. Prognostic value of serum resistin levels in patients with acute coronary syndrome. Kardiol Pol. 2014;72(2):181-6. DOI: 10.5603/KP.a2013.0086

30. Rosner B. Fundamentals of biostatistics. 5th ed. Pacific Grove, CA: Duxbury; 2000.

31. Zhang MH, Na B, Schiller NB, Whooley MA. Association of resistin with heart failure and mortality in patients with stable coronary heart disease: data from the heart and Soul study. J Card Fail. 2011;17(1):24-30. DOI: $10.1016 /$ j.cardfail.2010.08.007

32. Anfossi G, Russo I, Doronzo G, Pomero A, Trovati M. Adipocytokines in atherothrombosis: focus on platelets and vascular smooth muscle cells. Mediators of inflammation. 2010;2010:174341. DOI: $10.1155 / 2010 / 174341$

33. Considine RV, Sinha MK, Heiman ML, Kriauciunas A, Stephens TW, Nyce MR, et al. Serum immunoreactive-leptin concentrations in normal-weight and obese humans. N Engl J of Med. 1996;334(5):292-5. DOI: 10.1056/NEJM199602013340503

34. Piemonti L, Calori G, Mercalli A, Lattuada G, Monti P, Garancini MP, et al. Fasting plasma leptin, tumor necrosis factor-alpha receptor 2 , and monocyte chemoattracting protein 1 concentration in a population of glucose-tolerant and glucose-intolerant women: impact on cardiovascular mortality. Diabetes care. 2003;26(10):2883-9. DOI: 10.2337/diacare.26.10.2883

35. Scholze A, Rattensperger D, Zidek W, Tepel M. Low serum leptin predicts mortality in patients with chronic kidney disease stage 5. Obesity (Silver Spring). 2007;15(6):1617-22. DOI: 10.1038/oby.2007.191

36. Sattar N, Wannamethee G, Sarwar N, Chernova J, Lawlor DA, Kelly A, et al. Leptin and coronary heart disease: prospective study and systematic review $\mathrm{J}$
Am Coll Cardiol. 2009;53(2):167-75. DOI: 10.1016/j. jacc.2008.09.035

37. Ku IA, Farzaneh-Far R, Vittinghoff E, Zhang MH, Na B, Whooley MA. Association of low leptin with cardiovascular events and mortality in patients with stable coronary artery disease: the Heart and Soul Study. Atherosclerosis. 2011;217(2):503-8. DOI: 10.1016/j. atherosclerosis.2010.10.047

38. Owens CD, Kim JM, Hevelone ND, Hamdan A, Raffetto JD, Creager MA, et al. Novel adipokines, high molecular weight adiponectin and resistin, are associated with outcomes following lower extremity revascularization with autogenous vein. J Vasc Surg. 2010;51(5):1152-9. DOI: 10.1016/j.jvs.2009.12.051

39. Osawa H, Doi Y, Makino H, Ninomiya T, Yonemoto K, Kawamura R, et al. Diabetes and hypertension markedly increased the risk of ischemic stroke associated with high serum resistin concentration in a general Japanese population: the Hisayama Study. Cardiovasc Diabetol. 2009;8:60. DOI: 10.1186/1475-2840-8-60

40. Rajpathak SN, Kaplan RC, Wassertheil-Smoller S, Cushman M, Rohan TE, McGinn AP, et al. Resistin, but not adiponectin and leptin, is associated with the risk of ischemic stroke among postmenopausal women: results from the Women's Health Initiative. Stroke. 2011;42(7):1813-20. DOI: 10.1161/STROKEAHA. 110.607853

41. Zhang MH, Na B, Schiller NB, Whooley MA. Resistin, exercise capacity, and inducible ischemia in patients with stable coronary heart disease: data from the Heart and Soul study. Atherosclerosis. 2010;213(2):604-10. DOI: 10.1016/j.atherosclerosis.2010.09.015

42. Krecki R, Krzeminska-Pakula M, Peruga JZ, Szczesniak P, Lipiec P, Wierzbowska-Drabik K, et al. Elevated resistin opposed to adiponectin or angiogenin plasma levels as a strong, independent predictive factor for the occurrence of major adverse cardiac and cerebrovascular events in patients with stable multivessel coronary artery disease over 1-year follow-up. Med Sci Monit. 2011;17(1):CR26-32. DOI: 10.12659/MSM.881325

43. Lubos E, Messow CM, Schnabel R, Rupprecht HJ, Espinola-Klein C, Bickel C, et al. Resistin, acute coronary syndrome and prognosis results from the AtheroGene study. Atherosclerosis. 2007;193(1):121-8. DOI: 10.1016/j.atherosclerosis.2006.05.039

44. Lee SH, Ha JW, Kim JS, Choi EY, Park S, Kang SM, et al. Plasma adiponectin and resistin levels as predictors of mortality in patients with acute myocardial infarction: data from infarction prognosis study registry. Coron Artery Dis. 2009;20(1):33-9. DOI: 10.1097/ MCA.0b013e328318ecb0

45. Efstathiou SP, Tsiakou AG, Tsioulos DI, Panagiotou TN, Pefanis AV, Achimastos AD, et al. Prognostic significance of plasma resistin levels in patients with atherothrombotic ischemic stroke. Clin Chim Acta. 
2007;378(1-2):78-85. DOI: 10.1016/j.cca.2006.10.023

46. Pilz S, Weihrauch G, Seelhorst U, Wellnitz B, Winkelmann BR, Boehm BO, et al. Implications of resistin plasma levels in subjects undergoing coronary angiography. Clin Endocrinol. 2007;66(3):380-6. DOI: 10.1111/j.1365-2265.2007.02743.x

47. Hoefle G, Saely CH, Risch L, Koch L, Schmid F, Rein P, et al. Relationship between the adipose-tissue hormone resistin and coronary artery disease. Clin Chim Acta. 2007;386(1-2):1-6. DOI: 10.1016/j.cca.2007.07.001

48. Luc G, Empana JP, Morange P, Juhan-Vague I, Arveiler
D, Ferrieres J, et al. Adipocytokines and the risk of coronary heart disease in healthy middle aged men: the PRIME Study. Int J Obes (Lond). 2010;34(1):118-26. DOI: $10.1038 /$ ijo.2009.204

49. Lim S, Koo BK, Cho SW, Kihara S, Funahashi T, Cho YM, et al. Association of adiponectin and resistin with cardiovascular events in Korean patients with type 2 diabetes: the Korean atherosclerosis study (KAS): a 42-month prospective study. Atherosclerosis. 2008;196(1):398-404. DOI: 10.1016/j.atherosclerosis. 2006.11 .017 